\title{
Ethnicity, Development and the Dynamics of Political Domination in Southern Matabeleland
}

\author{
Clifford Mabhena \\ Institute of Development Studies- National University of Science and Technology-Bulawayo, Zimbabwe
}

\begin{abstract}
This article argues that the hegemony of the Shona people in Zimbabwe has been largely influenced by ethnicity and the quest to dominate Matabeleland politically, socially and economically. Development marginalisation of Matabeleland region, I argue has been influenced by ethnicity and politics of revenge. The study used ethnography to collect data and hence in-depth interviews were used as data collection tools. The results of the study indicate that Matabeleland has been largely dominated by the Shona ethnic group, and arguments advanced by scholars for this dominance, it is argued, Ndebele dominated the Shona people in the $19^{\text {th }}$ and $20^{\text {th }}$ centuries. This was due to conquest by the marauding Ndebele warriors under the leadership of King Mzilikazi and latter on King Lobhengula. The ascendance of the Zimbabwe African National Union Patriotic Front (ZANUPF) in the 1980 independence elections opened the gates for the ascendancy of the Shona people as the party was pre-dominantly Shona speaking. The march to state house by the ZANUPF dominated party created a lot of tension between the two ethnic groups; Ndebele and Shona, and hence the lashing out of the fifth brigade in 1983 and 1984 in Matabeleland and Midlands provinces of the country.
\end{abstract}

Key words: Hegemony, ethnicity, internal colonisation, marginalisation

\section{Introduction}

Matabeleland is part of Zimbabwe, although history shows that some Ndebele are descendants of the Zulu and other ethnic groups from South Africa. The salutary history fact has had a profound impact on the political development of Zimbabwe and has fundamentally shaped the way in which Matabeleland is constituted within the Zimbabwean polity. It would be extremely difficult to understand the social, economic and political dynamics of southern Matabeleland without recognizing the role of ethnic conflict and persecution in the making of this region. In this article I argue that the current hegemony of the Shona people in Zimbabwe and their desire to dominate Ndebele communities in the south has contributed significantly to development marginalisation of southern Matabeleland over the past 30 years.

Internal colonialism has largely been shaped by historical and ethnic factors that have come to dominate the political landscape of Zimbabwe before and after independence. In post independence Zimbabwe the struggles for land dramatically shifted from white colonial occupation to local level struggles for land and resources by formerly marginalised communities as the government in 2000 introduced the Fast Track Land Reform and Resettlement Programme (FTLRRP). This programme shifted a large chunk of former commercial farm land from white farmers to black 'farmers' for both settlement and commercial farming. The article further focuses on the changing political landscape in the region since the 1980s and the growing significance of ethnic consciousness and identification in the politics of development. I suggest that a fundamental theme in this history has been the desire and quest by the ruling, Shona-dominated ZANUPF to construct, under the auspices of 'development', a system for the political domination and control of Matabeleland.

I begin by exploring the historical roots of the Shona-Ndebele conflict in Zimbabwe. Here I note that while there are significant cultural differences between these two ethnic categories, I also concur with scholars who stress the invented and flexible nature of ethnic construction and identity. I note that the definition and composition of both groups has changed historically in relation to struggles for resources and land and provide a background to the political desire for Shona domination in the post-1980 period. This provides the context for a discussion of the Gukurahundi campaign, which allegedly sought to root out political dissidents, but was effectively translated at the local level to an exercise in ethnic cleansing. The article documents some impacts of Gukurahundi on rural communities in the research areas and explores the consequences of this process for the dynamics of rural development in Matabeleland. The article argues that while the region has been exposed to a form of internal colonialism, the attempt by the ruling party to dominate and control rural communities in this region has largely been unsuccessful. Amongst the legacies of the ethnic violence of the 1980s is that there are low levels of trust of the state by local communities and a lack of commitment by the state to the local level development agenda. It is also noted that the state's lack of political legitimacy has resulted in it continuing to rely on a combination of coercion and co-option to achieve its objectives. A new 'strategy' by the people of Matabeleland south in 2013 was to re-task ZANUPF to address their plight by voting the party overwhelmingly; 
tasking mainly their Ndebele councillors and Members of Parliament to request the party to re-think 'development' in the region. This is yet to be evaluated in the next five years.

This article is based on a detailed ethnographic study conducted in Gwanda and Umzingwane districts of Matabeleland South from 2006 to 2010. The article also engages scholarly debates from literature on the socio-political and economic history of this region.

\section{Making of Ethnicity before Independence}

In my readings on the history of Zimbabwe I learnt that between the eighth and the tenth century AD, the Shona people occupied the area now called Zimbabwe, slowly displacing the Khoi-San people (Bushmen) who had occupied much of the country for several thousand years previously. The Shona were a cattle herding and crop-farming people. From about the eleventh century onwards, they built large stone buildings and towns of up to 20,000 people. The most famous of these is Great Zimbabwe, located 20 kilometers outside Masvingo town (Munro, 1994). The Shona kingdoms were significant powers and traded both with groups in the interior of Africa and with Arab, Portuguese and Indian traders on the coast of what is now Mozambique (Munro, 1994, Moore, 2005).

Towards the mid- $19^{\text {th }}$ Century, the Rozvi Empire, whose hereditary ruler bore the title of Mambo, was in a state of decline. The Rozvi were further weakened when an Nguni group under the leadership of Zwangendaba killed the ruling Mambo. By the time the Ndebele arrived under the leadership of Mzilikazi ${ }^{1}$, they found the Shona communities scattered and without leadership. There was therefore little organized resistance to the settling of Ndebele in what is now Matabeleland, in Southern and Western Zimbabwe (McGregor, Alexander and Ranger, 2000). Ranger (1999) acknowledges that the arrival of the Ndebeles in present day Zimbabwe meant the incorporation through coercion and cooption of tribes such as Kalanga, Jahunda, Banyubi and Lozwi into what became the Ndebele state. Their incorporation was not by design, but the result of conquest. In some cases the invading Zulus and Swazis (abeZansi and Abenhla) ${ }^{2}$ faced serious challenges as transcending the landscape, especially around the Matopos area; they had to depend on the advice and guidance of the indigenous inhabitants of these hills. Noel Hunt, a Native Commissioner during the early days of the colonization of Zimbabwe noted that:

The Ndebele Chiefs have been ruling these people ever since they emerged from the Congolese forests...They know how to rule blacks. When the white man came to Rhodesia, you did not have to consult any Mashona or Karanga or anybody else at all because they'd all been conquered and defeated by the Amandebele. The de-facto rulers of every square inch of land and the de-facto rulers of every single head of cattle in Rhodesia were the Amandebele, (Hunt in Alexander, McGregor, and Ranger 2000:93).

Yet these sentiments had serious consequences for the inhabitants of Matabeleland in post independence Zimbabwe, as we shall see in relation to the 'Gukurahundi' conflict, and the rhetoric of its predominantly Shona soldiers later on.

The first permanent white residents of Zimbabwe, then Rhodesia, were a tiny number of missionaries who arrived in the 1850s and 1860s, though a few Portuguese traders, soldiers and missionaries had penetrated into Zimbabwe as early as the 1500s (Moore,2005). White settlers began arriving in large numbers with the 'Pioneer Column' in 1890, looking initially for precious minerals but later deciding to stay for the country's agricultural potential. In 1893 and 1896, respectively, the Ndebele and Shona uprising against the white settlers were crushed, in what is popularly termed the 'first Chimurenga', or war of liberation (Munro, 1994:9). The second Chimurenga was the bitter and protracted guerilla war waged intensively in the 1970s by (Zimbabwe Peoples' Revolution Army (ZIPRA) and Zimbabwe African National Liberation Army (ZANLA) guerillas of the Patriotic Front. ${ }^{3}$

When the Matabele were defeated in 1893, they had sought refuge in the Matopos hills south of Bulawayo. Because of the scenic nature of the hills, and the need for cheap labour for the mines, Rhodes persuaded the Ndebele chiefs to come out of the hills to pave way for the establishment of a nature reserve which was in later years to be named Rhodes Matopos National park. ${ }^{4}$ All arable land around Bulawayo was alienated to whites and blacks were moved to dry land that lay south of the Matopos in what became the present day Gwanda, Matobo and Umzingwane districts. The annual report by the Native Commissioner, Matopos, for the year ending March 1900 commented that:

\footnotetext{
${ }^{1}$ Mzilikazi son of Matshobana was one of King Shaka's chief induna who fled his brutality during the umfecane era. He was the first king of the Ndebele nation and like Cecil Rhodes, is buried in the Matopos hills, at Entumbane.

${ }^{2}$ See William F. Lye (1969), The Ndebele Kingdom South of the Limpopo. Here he emphasises that the core Nguni group was referred to as abeZansi (southerners) and Abenhla (those incorporated to the Ndebele state in present day Mpumalanga, Gauteng and Limpopo provinces of south Africa in the early $19^{\text {th }}$ century).

3 See Barry, 2004; Zimbabwe, The Past is the Future, p31, The Zimbabwe Liberators Platform: What happened to our dream?

${ }^{4}$ The National park has since dropped the name "Rhodes" in a move to give local names to national institutions and enterprises.
} 
There are large tracks of uninhabited desert country in the west and south west of the district covered with Mapani trees. The Matopos range is the only part that can be said to be well populated (Ranger 1999:87).

\section{Chieftainship and Ethnicity in Wenlock}

The notion of ethnicity is both amorphous and imbued with extreme doses of subjectivity. Kellas (1998), for example defines ethnicity as a state of being ethnic, or belonging to an ethnic group. On the other hand the United Nations defines ethnicity as referring to membership in a culturally and geographically defined group that may share language, cultural practices, religion or other aspects. Within these national groups there are further divisions that can be termed as ethnic groups; for instance South Africans can be of Zulu, Xhosa, Sotho or Venda ethnic groups. The same can be said of Zimbabwe where the prominent ethnic groups are Ndebele and Shona. Some scholars have tried to distinguish between nationality and ethnicity. The United Nations (2005), views nationality as referring to country of citizenship; however some scholars and development practitioners use nationality to mean ethnicity, although the two terms are technically different. It is therefore important to note that people can share the same nationality but be of different ethnic groups and at the same time people of the same ethnic identity can be of different nationalities.

Eriksen (2002) comments that Weber (1980) [1921] discarded ethnic community action as an analytical concept since it referred to a variety kinds of phenomena. Weber in Eriksen (2002) also held that 'primordial phenomena' like ethnicity and nationalism would decrease in importance and eventually vanish as a result of modernisation, industrialisation and individualism. On the contrary, ethnicity, nationalisms and similar forms of identity politics grew in political importance in the world throughout the $20^{\text {th }}$ century, particularly since the Second World War (Eriksen, 2002:2). In everyday language the word ethnicity still has a ring of 'minority issues' and 'race relations', but in social anthropology it refers to aspects of relationships between groups which consider themselves, and are regarded by others, as being culturally distinctive. Although it is true that 'the discourse concerning ethnicity tends to concern itself with sub-national units, or minorities of some kind or another (Chapman et al. 1989:17), majorities and dominant peoples are no less "ethnic" than minorities (Eriksen, 2002:4). In contrasting racism and ethnicity, Banton argues that ethnicity is generally more concerned with the identification of "us", while racism is more oriented to the categorisation of "them" (Banton, 1983:106cf, Jenkins, 1986:177). To Banton it implied that race is a negative term of exclusion while ethnic identity is a term of positive inclusion. Mitchell (1956) further explores the 'us' and 'them' ethnic classification using the Kalela dance. ${ }^{5}$ This resulted in him concluding that the concept of stereotyping refers to the creation and consistent application of standardised notions of the cultural distinctiveness of a group. This led to Eriksen's argument that stereotypes are held by dominated groups as well as by dominating ones, and they are widespread in societies with significant power differences as well as societies where there is a power equilibrium between ethnic groups (Eriksen, 2002:24). This brought him to the conclusion that ethnicity is a product of contact not of isolation, and the idea of an isolated ethnic group is meaningless. By implication, ethnicity entails both commonalities and differences between categories of people-both complementarisation and dichotomisation (Eriksen 2002:35) ${ }^{6}$.

Ndebele is a grouping of various ethnic groups that reside in Matabeleland. These are the core groups who came to Zimbabwe under the leadership of Mzilikazi; the Kalanga, the Sotho, Venda, Jahunda, Nanzwa (Nambiya) and other smaller groups that were already resident in the area, However early colonial administrators tended to present a complex ethnic picture of the region, especially the area around Matopos hills where I conducted numerous interviews and personal observations during the course of this study. Ranger (1999) acknowledges that the colonial administrators saw the indigenous Banyubi people of the hills as the very much non-Ndebele-Assistant Native Commissioner Umlugulo (sic) noted in a March 1900 report that 'the most ignorant and coward natives I have seen, almost the whole population being a very poor class of the MaHoli'. The word 'Amahole' was used derogatorily by the Ndebeles to refer to tribes other than the Swazi and Zulu who had an Nguni affinity". Jackson reported that if 'the bulk of the people are of the Banyubi hill tribe occupying the rugged Matopos range...the subsidized Indunas are Matabele ${ }^{8}$ Indeed there is evidence that different sorts of 'non-Ndebele' who lived in the hills in the mid 1890s felt not only different from but actively hostile towards their Ndebele overlords. Many Shona speakers, captured in Ndebele raids before 1893 and placed under Ndebele Indunas in or around Matopos, now took the opportunity to escape after the collapse of the Ndebele rule. Assistant Native Commissioner Mlugulu in June 1897, for instance, reported that:

\footnotetext{
${ }^{5}$ See Mitchell (1956) in Eriksen 2002:23). Though the Kalela dancers were dressed in a modern way and the dance was not part of their traditional cultural repertoire, the dance itself, songs and the message passed distinguished between 'us' and 'them.'

${ }^{6}$ See also Mitchell 1956 where he describes how an individual can behave as a 'tribal' in some situations and 'town dweller' in others.

${ }^{7}$ Williams (1969): The Ndebele kingdom south of the Limpopo.

${ }^{8}$ Monthly report, Matopo-Mawabeni June 1899, NBE 1/1/1.
} 
A great many Amahole who were placed under either Hluguniso or Dhliso have left 'Egubeni' for their original homeland, 'Ebuswina', near Victoria (now Masvingo). They have no intention of returning. It appears that all Amahole in the Matopos Hill are desirous of seeking pastures new, (Ranger 1999:100).

After 1896, the Native Department officials did not wish to reconstruct the Ndebele state. Instead they tried to hold the societies of central Matabeleland together by constructing an 'Ndebele' ethnicity on what was perceived to be Zulu cultural practices. For instance colonial administrators enforced payment of lobola (brideprice) which they thought characteristic of Nguni societies and discouraged the bride service on the Banyubi practice ${ }^{9}$. Indunas and their courts were entrusted to enforce marriage law so that the domestic issues of the Banyubi, Kalanga and other groups were determined in isiNdebele before an Ndebele induna. Missionaries used isiNdebele or more often Zulu as a language of church and school (Ranger 1999:101).

The construction of an Ndebele nation or 'community' through the incorporation of various ethnic groups supports the idea raised by Anderson that all communities are invented and using his words 'imagined communities'. The construction of an 'Ndebele ethnicity' shows that while it was initially invented to facilitate colonial rule, it was the Ndebele themselves who subsequently made the label meaningful, and at various times contested its meaning (Schech and Haggis 1991:281). Schech and Haggis further argue that while 'Ndebele' was crafted out of various ethnic groups, missionaries were central in classifying and naming groups of local people reified as tribal groups, whose access to missionary and colonial resources was contingent on their newly ascribed social identities. Inscription (of local languages) and ascription (of identities based on apparent differences in language) were key processes in this phenomenon. Chimhundu (1992) argues that at successive meetings of the Southern Rhodesia Missionary Society Conference (SRMSC) during the 25 year period from 1903 to 1928, several rival missionary societies operating from Mission Headquarters conveniently situated far away from one another were brought together by common interests to discuss a single ortholography for Shona, which they all needed to use for evangelical work in their respective zones of operation. The development of written literacy and the shaping of ethnic identities were key outcomes of this conference. Ranger argues the same for the case of Matabeleland where missionaries developed written literacy and missionary activities around the Zulu language despite the presence of other ethnic languages such as Kalanga, Nyubi and Sotho for instance. Ranger (1993:64) argues that ethnicity was created not only by colonial officials, but was also imagined and manipulated by African nationalist politicians, church leaders and others. On the other hand Moyana and Sibanda (1999) argue that there was peaceful cross fertilization of ideas and beliefs between the Shona and the Ndebele groups (1999:18-19).

\section{Traditional structures as colonial agents}

Zimbabwe's independence in 1980 marked the end of 90 years of colonial rule. Prior to colonization, the indigenous black people had social institutions that governed its members. For instance, the institution of the King (inkosi) in the Ndebele culture was respected as was the institution of the chief (mambo) in Shona society (Moore, 2005, McGregor, 2000, Ranger, 1999). Some of these institutions survived colonization; for instance chieftaincy remained a strong institution even during colonization. Chiefs were maintained by colonialists if they agreed to carry out administrative duties assigned to them. In some instances, disobedient chiefs were removed and replaced by ones appointed by the British and Rhodesia rulers. It was common in British territories to appoint chiefs as noted by Berry (1993).

Observations by Berry (1993) were common in most British colonies in Africa, and Zimbabwe then Rhodesia, was no exception. Where chiefs were very powerful and could not be intimidated by the British settlers, the latter introduced the concept of 'headmen', a phenomenon that exists in present day Zimbabwe. However, in contemporary Zimbabwe, the headman (umlisa) reports to the chief (induna), and is viewed as a representative of traditional authority in the absence of a chief. Below the headman, there is the institution of kraal head (usabhuku) (Scoones 1996, Moore 2005). The latter represent and present problems and proposals of a kraal and there can be as many kraal heads as there are kraals in the Chief's or Headman's area. The main function of these traditional institutions is to regulate the way of life of a particular society; thus traditional institutions sanctions norms, customs and values of a society. At kraal level, kraal heads are empowered by the chief to allocate land for fields and homesteads. It is worth noting that traditional positions in an ideal Zimbabwean cultural context are ascribed. However, the advent of democratic elected institutions like Rural District Councils, conflict has raged on between these institutions and traditional institutions (Mabhena and Bank 2011)

The 'concept' of headmen and kraal heads was an invented tradition in Matabeleland as an endeavour to exact control by the colonial administrators who felt some chiefs were disloyal and still haboured the idea to create a Matabeleland homeland. To the Native Administrators this could cause secession and hence the

\footnotetext{
${ }^{9}$ To be a son in law of a Banyubi household, the man had to work for the in-laws demonstrating his industriousness. Some oral evidence gathered by the author put the time-span at least seven years.
} 
appointment of these functionaries to diffuse the idea. It is associations like Sofasonke which grouped the inhabitants of the Matopos against evictions and the Old Nqama Regiment in Wenlock which claimed land taken over by white settlers in the early $20^{\text {th }}$ century (Ranger 199). The claim of land by these associations was locally and historically specific and it is worth noting that when independence came, the new resettlement models did not take these local claims into consideration thus letting outsiders settle in the acquired farms at the expense of those who had established their claim earlier, (Mabhena, 2010). Unlike in South Africa, the land reform programmes in Zimbabwe did not consider 'land restitution' as a model to address the dispossessions of the colonial era.

In Matabeleland, Kingship was paramount before Lobhengula 'disappeared'. After the fall of the Ndebele kingdom chieftainship assumed a paramount status and even when massive eviction of people from Matabeleland South to emaguswini (Matabeleland North) occurred, people moved with their chiefs (McGregor et, al 2000). In some cases Ndebele chiefs became rulers of the new land in spite of having found inhabitants in those areas. This was because when Mzilikazi drifted north towards to what is now Zambia, he had conquered and captured some of these subjects and when he drifted back southwards to die in the Matopos, his mark as a feared warrior was still vivid in the minds of the Abashankwe, Lozwi and Tongas of this area. Colonial administrators by 1939 had established a Chiefs council in the Matabeleland region. Alexander et al (2000) points out that in the beginning chiefs used this council to complain about lack of development, for instance inadequate schools, clinics, poor state of roads among many other demands. But later on under the influence of the Matabeleland Home Society, chiefs began to demand a just deal for the region from government. They cited better roads, schools and other social amenities in Mashonaland as compared to next to nothing in the Matabeleland region. These demands culminated in the great Matabeleland Home Society Conference that was attended by all chiefs, headmen and elders in December 1945. The conference demanded the formation of a chief's assembly in Matabeleland. This assembly was actually registered by the Native Commissioner in 1952 , (Kriger, 1988, Alexander et al 2000:91)

\section{The problems of eviction}

The introduction of the Land Husbandry Act in the early 1950s had a negative effect on the livelihoods of people in southern Matabeleland. This Act followed the Land Apportionment Act of 1930 that segregated land on racial lines. The 1930 Act was a reaction to the official agrarian planning of 1925. By 1951 the Land Husbandry Act was put into motion, (Ranger 1999). Commentators of this oppressive piece of legislation acknowledge that it was the work of agricultural experts and a duplication of the Betterment Planning in South Africa's former Homelands. ${ }^{10}$ The legacy of the Land Husbandry Act (1951) and centralization of planning resulted in the enforcement of the digging of contour ridges. Contemporary Zimbabwean land experts such as Moyo (1995) ascertained that the digging of contours (imigelo in Ndebele) was bitterly contested by chiefs and their subjects throughout the country. One can draw conclusions that the politics existing during the colonial era was evidence that the bigger question being addressed was that of land. The land dispossessions had confined black people regardless of ethnicity to marginal lands in all the then five administrative regions of the country.

I agree with scholars like Moyo (1995) that the land question was the impetus for the waging of the liberation war and in fact, the land question has a long history spanning before colonization when the Ndebele disposed the Karanga and the Kalanga of their land and livestock. This is why the lashing out of Gukurahundi under the disguise of hunting down dissidents was used to repossess lost 'power' over land and its resources by Shona people linked to the Mugabe party. In fact the politics of land redistribution in Matabeleland is closely linked to the dispossessions that happened in the $19^{\text {th }}$ century. The question to ask therefore is what relevance does this history have on the current politics and the development discourse pursued by the mostly Shona dominated state? Does the current politics of land distribution favour or inhibit rural development in Southern Matabeleland in the current scenario of the FTLRRP?

\section{Transition to independence and Gukurahundi}

After a protracted armed struggle Zimbabwe finally attained independence in 1980. The people of Matabeleland believed that ZAPU and its military wing ZIPRA had fought the war decisively and deserved to rule the country; but that was not to be the case in the 1980 elections when ZANU PF and its ZANLA guerilla movement emerged victorious in a land slide victory.

The delegation to the Lancaster House Constitutional Conference in $1979^{11}$ went under the banner of the 'Patriotic Front', and this created a feeling among the guerilla group and its supporters that whatever agreement was reached on the Zimbabwe question, they were ready to act collectively. When the agreement was finally signed and paved the way for the first democratic elections, ZANU declared that it would contest the election

\footnotetext{
${ }^{10}$ See Ntsebeza: Democracy Compromised.

${ }^{11}$ The 1979 Lancaster house Conference was organised by the Thatcher government and paved way for elections in 1980.
} 
outside the Patriotic Front Alliance. ZAPU according to Nyathi (2001) was caught unaware and tried all avenues to maintain the alliance by even registering as the Patriotic Front in the general elections.

One may ask the question: why at the last minute an alliance, with the blessing of the Frontline states and the Organisation of African Unity, could decide to approach the elections separately. In many ways the Patriotic Front was a front of convenience-within it Mugabe continued to speak for ZANU, Nkomo continued to speak for ZAPU and the two parties continued to operate as independent entities. Hyden (2006) gives a useful observation of the tendency of African leaders when they are at the gates of assuming 'power'. Hyden (2006:59) states that: "even though the struggle against colonialism had brought them together in a more or less united front, their arrival at the gates of the state at independence forced upon them the challenge of working out a governance formula that accommodated those many contending group interests. In Kenya for instance, the Kikuyu who led the Mau Mau movement against the British in the 1950s claimed a larger share of the cake after independence. When Zimbabwe turned to majority rule in 1980, the Shona affiliated to Robert Mugabe's ZANU party demanded a similar deal". Hyden's observation supports the notion that the ethnic composition of ZANU $\mathrm{PF}$ and the limited positions of 'power' if they contested the elections as patriotic front, would deprive some close associates positions of power and authority in a new state. This probably is one of the explanations for ZANU PF deciding to go it alone. The other reason can be traced back to the split into ZANU and ZAPU in 1963 (Barry, 2004, Sithole, 2000, Ranger, 1999, Alexander et al 2000, Bhebhe 1995).

External factors contributed too; for instance President Kaunda in Zambia was supporting Nkomo of ZAPU while Nyerere of Tanzania preferred a ZANU election victory (Hyden, 2006). The tendency of African leaders to change goal posts at the last minute is not peculiar to Kenya and Zimbabwe but common to other African leaders and parties when they are knocking at the doors of the state. Hyden (2006) acknowledges that in other African countries, the process of gaining control of the state entailed similar issues of bargaining for advantages and preferences. Hyden further noted that in Africa the state is an arena from which to draw as much resources as possible. So if the two parties had contested the elections as the Patriotic Front, the competition for positions of power and authority would have been stiff. Raftopoulos and Phimister (2004) noted that even prior to independence the unification of ZIPRA and ZANLA under Zimbabwe People's Army (ZIPA) faced some setbacks because it was clear that Robert Mugabe was not for the idea. ${ }^{12}$

Joshua Nkomo the leader of ZAPU, a strong believer in traditional shrines, and a Kalanga by birth, took his election campaign on $24^{\text {th }}$ February 1980 to Njelele where over 300000 people from all over the country converged to celebrate what they thought was the victory of ZAPU under its election tag Patriotic Front. The reason why Nkomo opted for Njelele, some commentators believe, was an effort to report to the ancestors that they had brought back their land stolen by white settlers. Again they had defeated the enemy because of their guidance; hence a big thank you was befitting Njelele, the supreme God shrine. Nkomo in his classic book, The Story of My Life, 1984, states that he had thirty years earlier, been informed by the voices at Dula that it will take thirty years to reclaim the land, and 1980 was exactly thirty years since that pronouncement, and hence the belief by residents of Matabeleland that ZAPU would win the election despite the split of the Patriotic Front.

The day coincided with heavy rain, thunder and lighting and that, to the people present, was a sign of appreciation by the ancestors (Mabhena, 2010). An interview with Masuku revealed that Nkomo had blundered by assembling such a large number of people near the shrine because the shrine had its own special people to consult, and feasting on the vicinity of the shrine was taboo according to the Banyubi tradition ${ }^{13}$.

On the $4^{\text {th }}$ of March 1980, election results were announced by the Commonwealth Secretary General Sir Shridath Ramphal. ZANUPF won 57 parliamentary seats out of the 80 contested by blacks; PF won 20 in the Matabeleland constituencies, in those Midlands areas where there was an Ndebele presence, and parts of Mashonaland West where ZIPRA forces had been very active during the war. The minority parties won only three seats (Stoneman and Cliffe, 1989:34-35). ZAPU loss at the polls came as a shock to many of its supporters. ZAPU supporters as well as ZIPRA guerillas and the party leadership were convinced that ZANU PF's victory could only have resulted from foul play (Nkomo, 1984:210). With this defeat, local ZAPU leaders thought 'only freedom for Mashonaland' would follow. Thus the ZANU PF leaders were now ready to take the reins of power. Sithole (2000), views the ethnic divide as contributing to the defeat of ZAPU in the elections. The Shona constituted about $80 \%$ of the black population whereas the Ndebele (from which ZAPU drew much of its support) constituted only $20 \%$ and inhabited areas around Bulawayo. Ndebeles had dominated the Shona prior to the imposition of colonial rule. At independence the Ndebele lost their pre-colonial dominance to the ascendant Shona, who were the beneficiaries of a democratization process. The victorious ZANU PF invited PFZAPU to form a coalition government and Nkomo became the first Minister of Home affairs, also in charge of the police. Nkomo had earlier on declined the offer of ceremonial president, a post that was later on taken by

\footnotetext{
${ }^{12}$ See also Stoneman and Cliffe (1989:23-24). during the formation of ZIPA Mugabe was in detention in Mozambique

${ }^{13}$ My interview with Masuku an elderly resident of Njelele area on 18 April 2006 informed me that if a large group feast on the vicinity of Njelele shrine the gods get angry and this affects the rain patterns in the country. 
Canaan Banana, an Ndebele ${ }^{14}$. During this early period the British were busy integrating the three warring armies, ZIPRA and ZANLA guerillas and the Rhodesian forces to form the Zimbabwe National Army (ZNA). ZAPU and ZANU had historically been suspicious of each other as the discovery of arms caches on ZAPU owned properties was enough evidence for ZANU PF to dismiss ZAPU from the coalition government (Nkomo 1984: 234-244; Sithole 2000:71). Those farms and other properties were confisticated by the ZANU PF government in a march into Matabeleland. ZANU PF got support from its "civilian core-supporters" among ethnic Shona who approved the harsh and repressive measures emitted by the regime in Matabeleland and the Midlands (Sithole 2000:73). Bourgi France (cf Richards, 1999) gives a classical view-point on the ascendancy of Museveni's National Resistance Movement in Uganda when it took over the state. Bourgi in the Ugandan context, viewed power as being reconfigured not only on the basis of principles advanced by outside forces, but through the forging of new domestic arrangements that combine hegemonic and participatory principles (cf Richards, 1999:67). The view by Bourgi on Uganda is applicable to the Zimbabwean scenario as ZANUPF struggled to gain power in Matabeleland, through the introduction of unpopular local government structures. With the dissidents destroying Government property in the two Matabeleland provinces and the Midlands, the government decided to form a separate Brigade known as the $5^{\text {th }}$ Brigade. The North Koreans provided technical training and logistics. In what I call the 'overt sphere', the brigade was formed to deal with the dissident menace whilst in what I call the 'covert sphere' was an attempt to reclaim Matabeleland from the Ndebeles.

\section{Gukurahundi and revival of ethnicity}

Gukurahundi is a traditional Shona term, which means the early rain which washes away the chaff before the spring rains (CCJP, 1989). In post independent Zimbabwe, the term Gukurahundi is a euphemism used for the actions of the Fifth Brigade in the provinces of Matabeleland and the Midlands during the early to the late 1980s. The Catholic Commission for Justice and Peace (CCJP) revealed that in October 1980, the then Prime Minister Robert Mugabe signed an agreement with the North Korean President, Kim 11 Sung that they would train a brigade for the Zimbabwe National Army. As per the agreement in August 1981, 106 Koreans arrived to train the new brigade, (Nkomo 1984:223), which the then Prime Minister said was to "deal with dissidents and any other trouble in the country"15 Joshua Nkomo, leader of the mostly Ndebele ZAPU, asked why this brigade was necessary, when the country already had a police force to handle internal problems. He suggested the ruling party would use the fifth brigade to create a one party state. The Prime Minister replied by saying dissidents "watch out" (CCPJ, 1989) and further announced that the brigade would be called "Gukurahundi". A retired Colonel I interviewed revealed to me that this brigade was composed of 3500 exZANLA troops from Tongogara Assembly point, just a few ZIPRA (who were later on withdrawn) and Tanzanians. In their fieldwork Alexander et al (2000) also found that the Fifth brigade was dominated by Shona speakers, while civilians made repeated reference to non-Zimbabweans within their ranks. They were usually identified as Mozambicans, due to the use of Portuguese and Sena; others referred to soldiers having nose rings, complexion that were darker than normal and rather strange features (Alexander et al 2000:218). The first commander of the Brigade was Colonel Perence Shiri. ${ }^{16}$

The Fifth Brigade was different from all other army units, in that it was not integrated into the army. It was answerable only to the Prime Minister and the ZANUPF central committee and not to the normal structures of the army (Nkomo 1984); their codes, uniforms, radios and equipment were not compatible with other army units. Their most distinguishing feature in the field was their red berets. In February 1983, the brigade was deployed in Matabeleland North and exactly a year later in February 1984 was deployed in Matabeleland South. The operations of the Fifth Brigade in both the Matabeleland provinces was similar and carried the same rhetoric that all Ndebeles were dissidents, needed to be eliminated, and had raided the cattle of their ancestors in the $19^{\text {th }}$ century and hence revenge was inevitable. During this period a 24 hour curfew was imposed, depriving residents of access to food and other livelihoods.

Alexander, McGregor and Ranger (2000) in their fieldwork in northern Matabeleland reveal that the Fifth Brigade directed its energies to political mobilization over and above the massacre of civilians, what Ranger and Bhebhe aptly describe as "politicization without politics" (1995:19). From one interview Alexander and Ranger transcribed a text by one headmaster citing misconceptions by one Gukurahundi commander who insisted that ...dissidents had been at the school that day;

\footnotetext{
${ }^{14}$ My familiarity with ZANUPF politics suggests that though in practice is dominated by Shona ethnic group, the leadership of the party try to portray a national character by incorporating a hand full of Ndebele sympathisers into less important position of power. The appointment of Reverend Canaan Banana is a good example.

${ }_{15}$ Dissidents were a mixture of deserters from the ZNA, and discontent former ZIPRA Forces after factional fighting in Entumbane and other urban assembly points. Later on there was a claim that Apartheid South Africa was supporting them under the name Super ZAPU. Some claim that they were state agents

${ }^{16}$ Retired Colonel (Zimbabwe National Army,) now A2 farmer in Gwanda District- interview 15/12/2005. 
"We were surprised for we had not seen or heard of any around the school. On trying to prove and explain to them we just found ourselves being beaten again of not knowing Shona language which they were using" ( One headmaster quoted in Alexander et al 2000:218).

The brigade's operations were crucial in giving a political and ethnic meaning of the violence. The almost entirely Shona speaking brigade regularly used an overtly tribal and political discourse, and it's all encompassing violence could not be explained as militarily motivated. The Fifth Brigade commanders and soldiers told people that they had been ordered to 'wipe out the people in the area', to kill anything that was human...that the Ndebeles were dissidents, making women and children as well as men targets. "The child of a snake is a snake" as one respondent put it (Alexander et al, 2000:222, Hammar, 2006). Ironically ZANUPF politicians and the Fifth brigade soldiers sought to enhance and exploit ethnic divisions among the 'Ndebele' as they tried to convince the "Kalanga" that they were in fact Shona, and also tried to convince the "Tonga' that they should distance themselves from the trouble making "Ndebele". Turton (1997) and Fardon (1996) argued that ethnicity is powerful precisely because it can come to be perceived and experienced as an ancient, unchanging, natural source of identification and difference. In my fieldwork, informants constantly referred to the Gukurahundi era as one of the recent overt actions by ZANUPF that the Matabeleland landscape should be transformed to show a significant presence of the Shona ethnic group. This is demonstrated by evidence collected which showed that after this era, many Shona people began to settle in resettlement areas in Matabeleland South.

Acts of violence perpetuated by the Fifth brigade were given specific local meanings as a result of its tribalistic rhetoric. For example, McGregor et al 2000 noted that rapes committed by ZNA soldiers and dissidents might be described simply as abuse of power; rapes committed by the Fifth brigade were perceived to be a systematic attempt to create a generation of Shona children. Such interpretations extended to the meanings attached to development projects linked to the conflict; these initiatives were not seen as 'developmental' in intent but as heralding the introduction of Shona students to Matabeleland ${ }^{17}$. Other commentators used 'tribal' explanations much more explicitly to describe the dominant Shona state in handling the situation in Matabeleland; for instance a Guardian reporter spoke of 'a thousand years' of hostility between the 'Ndebele and the Shona'; Observer correspondents emphasised the 'tribal basis of Zimbabwean politics, and added that "the Shona" had good reason to hate the 'Ndebele', who in the $19^{\text {th }}$ century had specialised in roasting Shona babies alive (Ranger 1985:3). Makambe (1992) accused dissidents of representing 'an exclusively Ndebele political outfit and murdering both 'Ndebele" sell-outs and Shona opponents. Makambe wrote that in response "the reaction of the wider Shona society was both swift and violent and cites calls for draconian government action to prevent "all...Shona being eliminated (Makambe 1992:20, 34, 69). The dominant position of Shona in bureaucratic positions was also indicative of the thrust to turn Matabeleland into an object of development with the Shona ethnic group at the helm.

\section{Development, Changing Authorities and Internal Colonialism 1980-1988}

Barrera states that the term 'internal colonialism denotes "a structured relationship of domination and subordination which is defined along ethnic and /or racial lines, when the relationship is established or maintained to serve the interests of all or part of the dominant group...in which the dominant and subordinate populations intermingle" (1997:194). Bohmer (1997) further indicates that in this process, governments must actively participate to create internal colonies, providing coercive force to control those who are colonized, while legitimating patterns of domination with laws. The argument raised by Barrera (1997) and Bohmer (1997) is true in the case of southern Matabeleland as the state felt obliged to control the region. However, in the case of southern Matabeleland political domination by the state and its apparatus was the primary aim and not exploitation of economic resources. Colonialism is usually associated with the extraction of resources from subject populations but in the case of southern Matabeleland, the state went through the motions of development in a very uncommitted fashion and tended to be satisfied that it had achieved its objectives as long as the necessary political structures and controls had been put in place. Domination and exclusion were more important than exploitation of resources and the ability to exploit, in situations where that was intended, was undermined by resistance. This resistance is shown by the state resorting to the politics of patronage in the allocation of resettlement land. For instance, resistance by people in southern Matabeleland to move to resettlement areas such as Nyandeni in 1984 resulted in the state bussing people from other provinces to occupy these schemes an endevour that has seen conflicts between these people and the locals. The control of district and local authorities by people aligned to the ruling party was viewed as necessary by the state in an effort to assert power and authority in the region that had been dominated by ZAPU people.

Therefore, development practice was also shaped by both the politics of the new state and 'military hazards'. With ZAPU dominated District Councils, the state felt its control over the resources and development

${ }^{17}$ Personal experience of the author. 
of Matabeleland was being frustrated, and therefore an alternative development structure should be put in place to provide checks and balances on the activities of ZAPU councillors. In its endeavour to pursue this line of thought the state introduced new cadres at the District Administrators office, the Local Government Promotion Officers (LGPOs). LGPOs were mainly drawn from Ex-ZANLA guerillas and received some basic training in Local Governance at Domboshawa Public Service Training Centre. Their mandate was to promote the establishment of Village Development Committees (VIDCOs) and Ward Development Committees (WADCOs). These new institutions came into being after the Prime Minister's directive of 1984 which also saw the establishment of the posts of Provincial Governors; the latter being appointed on loyalty to the ruling party by the Prime Minister. LGPOs did not get the co-operation they demanded from the communities of the region as they were distrusted because of their ethnicity. In some circles the formation of VIDCOs was regarded as a ZANU PF mechanism for controlling Matabeleland (Stoneman and Cliffe, 1989). In state rhetoric, VIDCOs were there to promote local decision making and should be viewed as structures promoting democratic governance. Dahl, in characterizing democracy contends that governmental responsiveness to citizens on a continuing basis requires that citizens being given an opportunity to formulate preferences, signify their preferences to their fellow citizens and the government by individual and collective action; and have those preferences 'weighed equally in the conduct of government (cf Richards, 1999:40). In southern Matabeleland citizens were neither given the opportunity to formulate preferences nor signify their preferences. Development discourse was more hegemonic than democratic and more resources went to Mashonaland provinces.

The introduction of LGPOs coincided with the launching of the Mass National Literacy Campaign. Ironically, District Literacy Coordinators who spearheaded the campaign at district level in Matabeleland were drawn exclusively from ex-ZIPRA combatants, largely because of their conversancy with the Ndebele language. The logic behind this may be explained by the notion that literacy and numeracy teaching was conceived nationally and only possible if promoted in the mother language of the participants, as shown by UNESCO studies Worldwide. The role of District Literacy Coordinators was not seen as threatening as they had no influence over policy matters like their counterparts (LGPOs), who were directly involved with local government institutions. In their role of establishing VIDCOs, LGPOs had to carry out political re-orientation for the members of these committees; and one of the key attributes of being a member was loyalty to the state and the party. This caused serious development problems as people were reluctant to partake in these committees for various reasons: VIDCO members were targets of dissidents who regarded them as sell outs, while on the other hand the state would only channel development aid through these institutions. The hatred of VIDCOs was further exacerbated by Governor Mark Dube who noted in the Herald of $2^{\text {nd }}$ September 1983;

"The menace of dissidents is going to be destroyed. With the introduction of the new VIDCO system we will know each other at village level. Strangers will be required to produce letters of introduction. This will help root out robbers who steal from us and kill us".

Caught in this 'catch 22' scenario, development planning moved at a snail's pace in Matabeleland. The process of extending the reach of the state marginalized traditional authorities in the country and was a sign of a confident new regime forging ahead for its vision of modernity for the young nation (Raftopoulos 2004:5). With ZAPU councillors and local traditional leaders sidelined, VIDCOs and WADCOs took centre stage in an effort to promote rural development under instruction from LGPOs who also took over the distribution of drought relief from the Department of Social Welfare. With drought relief distribution an added responsibility for LGPOs, local people were forced to co-operate or else starve. Drought relief became a 'carrot and stick' affair. This further aggravated the precarious positions of locals and made them more vulnerable to the dominance of state agents.

The land resettlement programme in this part of the country suffered a setback as people were unwilling to leave their communal areas for the newly acquired resettlement schemes. Residents of Matabeleland South pin their hopes for a livelihood on livestock, and any development programme that does not take on board security of livestock is assured of failure. Alexander (1991) concludes that political conflict undermined effort by local leaders to lobby ministries and establish patron-client relationship with national politicians. For much of the 1980s, the states relationship with the people of Matabeleland was shaped by military and political, not developmental goals (1991:582).

Hyden (2006) argues that the 'state' in Africa is problematic for three specific reasons: it lacks autonomy from society that makes it an instrument of collective action. Instead it tends to respond to community pressures and demands that undermine its authority as a public institution. It fails to operate as a corporate entity, a system (2006:65). In the case of Matabeleland I tend to disagree with Hyden in the sense that people from this region had made it clear to the state that the best resettlement model is that which will give preference to livestock raising but the state would not listen. In this scenario the pressure and demands from the locals have been interpreted as subversive. The second reason advanced by Hyden is that state officials do not adhere to the formal rules that constitute public authority. They tend not to distinguish between what is private and what is public, with the result that citizens lose confidence in their readiness to act in the public interest and instead look 
at these officials as primarily motivated to feather their own nests using public resources (2006:65). The Willogate motor vehicle scandal in 1988 (Barry 2004:7), and the lease grazing on unsettled farms in Matabeleland by civil servants and politicians are two cases that support Hyden's theorization of a typical African state. Lastly Hyden contends that individuals appointed to public office rarely subordinate their personalities to the definitions of the role that they are expected to perform. This augurs well with his theorization of the economy of affection whose core principles is that who you know is more important than getting things done (2006:72). Hyden concludes by noting that the state in Africa is not an independent system of power that operates predictably and provides guidance to society. It is not the kind of "development machine" that nationalist leaders had hoped for and International donors expected to find in a place for their funding (2006:65). Hyden says that things get personal in such states, but in this case there was a systematic attempt by ZANU PF to structure power in predicable ways. They created a development model in their own image and interests. The introduction of villagisation and 'grids' (Robins, 1994), met stiff resistance from residents of Gwanda (Mabhena, 2010).

\section{Post-Unity and the development agenda 1987-2007}

The use of a coercive apparatus to force people in Matabeleland to submit to state hegemony was tested in the 1985 parliamentary elections. Having unleashed the Gukurahundi in 1983 and 1984, in Matabeleland, ZANU PF lost all seats in this region and it was obvious that it could not rule Matabeleland without the cooperation and support of ZAPU. Roseberry (1994) states that hegemony maybe shaped overtime among many variables talking about it, and acting upon it, but the issue of dominance of the state over the community remains. Roseberry in this sense argues that state-community relations may be interpreted as hegemonic processes that overtime develop "a common discursive framework"; a shared state authorized language of cognition, control and contestation (1994:363). Taken from Roseberry's argument, there are two schools of thought about the unity agreement between ZANU PF and ZAPU. The first is that for ZANU PF to rule the entirety of the country, ZAPU was a necessary evil to win support in Matabeleland and hence the strategy to incorporate it into ZANU PF. In the process the ruling party should maintain hegemony. Since the use of a coercive apparatus had not yielded the desired results, a negotiated 'incorporation' was inevitable. The other school of thought from which critical debates have emanated since the unity accord in 1987 is that ZAPU gave in to prevent further extermination of its supporters by state secret agents after the withdrawal of the Fifth brigade. After two years of negotiations the unity agreement was signed on $22^{\text {nd }}$ December 1987 by Joshua Nkomo representing ZAPU and Robert Mugabe for ZANUPF. Close associates to the negotiation like the late Reverend Canaan Banana and Chiwewe acknowledged that the name ZANUPF bogged down negotiations several times (Chiwewe in Banana, 1989). Ncube in Banana (1989:166-73) argues that unity opened up or broadened "democratic expression". People were free to express their views without fear since the conflict had ended.

At a communal level, people were not happy about the unity though it brought an end to harassment by state agents and dissidents. They were bitter about the failure of the united party to acknowledge the atrocities committed by the Fifth brigade let alone embrace their quest for a resettlement model that catered for their livestock without necessarily moving them from their present location (Robins, 1994:103-4). One of my informants commented "Ndebeles take time to grapple with a situation... once they joined ZANUPF, they are more ZANU than ZANU, and you see these ZANU splitting all over". However scholars such as Ncube (1989) argue that unity was more a matter of loyalty than good sense. Dumiso Dabengwa, the former ZIPRA military intelligence supremo revealed in January 2008 when he quit ZANUPF that he was 'never' ZANU and was forced by loyalty since Nkomo his leader had accepted the unity terms ${ }^{18}$. On the development front unity saw the return of surviving ZAPU local leaders taking up again the positions of councillors. The VIDCO and WADCO system was revived and new elections were held of which most were filled by those functionaries who did not join the old ZANUPF during the 'dark days'.

From literature and the personal experience of this author, though development planning was largely participatory at district and provincial levels, the implementation of these plans remained a pipe dream as the central government brought development projects top-down. For instance, the members of the Provincial Development Committee (PDC) Matabeleland South (1999) complained that the problem with the provincial planning was that it was wholly ignored by central government. By implication, central government projects funded through ministries and donors mushroomed haphazardly without being drawn from the PDC plan. In one provincial planning meeting I attended on 30 March 2000, Provincial Governor Welshman Mabhena argued that Provincial plans are nothing but a waste of man hours due to the government's top down approach. Provincial planners in the same meeting queried whether there was a way to legally avoid planning altogether; they

\footnotetext{
${ }^{18}$ See Chronicle January 5,2008.
} 
condemned planning as the 'most difficult and frustrating activity', and the plans themselves as 'Tiger documents' that continuously decorate their shelves without the slightest chance of implementation.

Richards (1999) in theorizing local governance, democracy and development in Africa argues that, local governance has been an extension of the central state to the community (1999:285). He further notes that, for most of independent Africa, the promotion of local governance as an institution for advancing popular democracy and economic development has been a qualified success at best. However, as an institution for the provision of community services under the control of central government, it has largely been a failure (1999:285). Olowu advances two important contributions by local governance to economic growth: local governance can enhance allocative efficiency in the production of goods and services as they are the closest to the market; can help mobilise resources and mobilise support for the provision of social and economic infrastructure because of their proximity to the people and the knowledge of the locality (cf, Richards, 1999:287). Langrod has argued that local governance is contradictory to democracy by stating that;

"Since democracy moves inevitably and by its very essence towards centralization, local governance, by the very division which it creates, constitutes, all things considered, a negation of democracy. Local governance and democracy triumphant represent diametrically opposed tendencies," (cf Richards, 1999:290).

Olowu suggests that failure of local governance results in alternative structures such as local development associations, civil society organisations, and cites the Njangis in Cameroon as alternatives to pursue local socio-economic growth. In Matabeleland, the establishment of the Matabeleland Development Association in the mid 1980s was a reaction to the neglect of the region in the development process.

In all the development plans for the Matabeleland region, the Provincial Development Committees (PDC), the case that Matabeleland had been neglected prior to unity, graced the introduction of the development plans time and again in the late 1980s and the $1990 \mathrm{~s}^{19}$. The trend was the same at District level where the Rural District Development Committees (RDDC) sounded the same as their provincial counterparts. So the neglect of the Provincial Plan by Central Government meant a neglect of district development. This reveals how 'internal colonialism' subject those 'colonized' to the status of second class citizens as projects come top-down without consultation with the beneficiaries. As Ferguson (1990) argued, this does not result in tackling the problems bedeviling the would-be beneficiaries. Hansen and Stepputat (2001) also argue that hegemony also works through the development of technocratic programmes and institutions that govern by virtue of routines, internal bureaucratic logics, and allotted resources without being directed by political forces in any strict sense (2001:27). This 'bureaucratic hegemony ' as illustrated by the sentiments of the provincial planners in Matabeleland earlier on, may have been deliberately done to frustrate the development endeavour of the region by central government bureaucrats. For instance, the construction of Mtshabezi dam was done without consulting the locals and henceforth regarded as a national project depriving locals' access to its water. These sentiments have resulted in locals seeing the dam as having no value to their livelihood and instead complain that it has impacted negatively on their downstream activities such as nutrition gardens and water for livestock. The state has of late constructed a pipeline that links this dam with Umzingwane dam, supplying the city of Bulawayo with water, which is some one hundred kilometres away. This shows how central planning and indeed top down approaches to development subject locals to the agony of state power and authority.

The introduction of the FTLRRP, like the previous land resettlement models enforced in Matabeleland have seen conflict between communal residents and those resettled. The conflict in this region is compounded by the fact that residents of this region prefer a model that focuses specifically on decongesting communal areas in terms of livestock, not people. The FTLRRP still gives limited attention to livestock grazing land. Suffice to note that the A1 model is unacceptable to most residents of southern Matabeleland, but because the programme is top-down, communal residents have found themselves deprived of grazing land when people were settled on farms adjacent to their communal of which they expected the state to give first preference to them for grazing purposes

The major problem faced by people in Matabeleland is that the state plans for agricultural land reform, are based on the requirements of people in Mashonaland provinces who have suitable arable land and receive fairly good rains. This tendency has seen plans drawn up by experts in Matabeleland gathering dust. Without proper acknowledgement of the interests of Matabeleland residents, this led to the unity agreement being viewed as a trick to further underdevelop the region. Even the (MDC) has been viewed by people in Matabeleland as still harbouring the dominating tendencies of the Shona as evidenced by the split in 2005, which resulted in most of the Ndebele leadership forming a splinter MDC party as a reaction to these tendencies by the dominant Shona leadership of the party.

Richards (1999) in concluding his analysis of state conflict and democracy in Africa, acknowledges sentiments echoed by Ottaway (1999:316) that, the power of nationalism has globally arisen again since the disintegration of the Soviet Union. He further notes that this has resulted in a world in which it is becoming

${ }_{19}$ Matabeleland South, 5 year Development Plan 1990-1995. 
possible both to challenge existing power relations among ethnic groups and to re-think the territorial arrangements that put specific populations within current boundaries. This provokes me to pose a question; is Matabeleland legitimately placed as part of Zimbabwe considering its ethnicity and hegemony subjected to by the current state? This question might sound justifying secession but the reality is that if colonial boundaries remain unchallenged, some communities will remain objects of dominant ones.

Development marginalization of Matabeleland has seen many young people from this region resorting to un-orthodox means of earning a living such as gold panning and illegal migration to countries such as South Africa and Botswana (Mabhena, 2010). This has left southern Matabeleland with few able bodied persons to engage in either subsistence crop farming or livestock rearing.

I have shown how Southern Matabeleland has been 'internally colonized' and constructed as an object of development by the state in Zimbabwe. From this narrative, it is evident that southern Matabeleland and Matabeleland region in general, has been marginalized by the state in social, economic and developmental terms. Authors such as Alexander (1991) contend that the state relationship with people of this region has been based more on political and military confrontation at the expense of development. State initiated land reforms in the 1980s and 1990s failed to attract the majority of Matabeleland residents because the villagisation model of resettlement was against their wish for more grazing land. Those who took up the village resettlements found themselves targets of dissidents. The unity agreement of 1987 ushered a new era as peace returned to Matabeleland, though the same development discourse remained shaped at central government level in Harare even in other parts of the country; people of southern Matabeleland felt real development was a preserve of Mashonaland provinces. Against all odds, the people of Matabeleland have survived on this land through complex livelihood strategies (Mabhena 2010).

\section{Conclusion}

Ethnicity and the politics of domination have shaped the development agenda in southern Matabeleland. The 1980s conflict left this region without development initiatives for a number of years. The fact that projects were brought top down without consulting the locals resulted in a number of state initiated projects remaining as 'white elephants' in this part of the country as people had no interest in them. Again these 'white elephants' were as a result of a development system that focused mainly on political control. In the case of southern Matabeleland, the need to control the region by the ruling party, can then be concluded, led to political structures which created opportunities of placement of loyal party members in positions of power and authority. A majority of those placed in these positions were selected on ethnic lines.

\section{References}

[1]. Alexander, J. (1991), The Unsettled land: The politics of Land Redistribution in Matabeleland-1980-1990: Journal of Southern African Studies Vol. 17, No 4.

[2]. Alexander, J. McGregor, A. and Ranger T (2000), Violence and Memory: One Hundred Years in the Dark Forestse of Matabeleland, James Currey Oxford.

[3]. Alexander J, McGregor, A. and Ranger, T. War, Hunger and Displacement: An Analysis, 2000- books. Google.com (Ethnicity and the politics of Conflict: the case of Matabeleland).

[4]. Banton, M. (1993), Racial and Ethnic Competition. Cambridge, UK: Cambridge University Press

[5]. Barry, H. D. (2004), The Past is the Future. Harare: Weaver Press,

[6]. Barrera, M. (1997), Latinos and Education. A critical reader: books.google.com.

[7]. Berry, S. (1993), No Condition is Permanent: The Social Dynamics of Agrarian Change in Sub Saharan Africa. Madison. University of Wisconsin Press: 237

[8]. Bohmer, P (1999), African-Americans as an Internal colony: The Theory of Internal Colonialism in Readings in Black Political Economy (ed) Whitehead J and Harris K,H. Dobuque, lowa.

[9]. Bhebhe, N. (1988), The Evangelical Lutheran Church in Zimbabwe and the War of Liberation, 1975-1980 in Carl Hallen-creutz and Andrew Moyo (eds) Church and State in Zimbabwe, Gweru: Mambo Press.

[10]. Bhebhe, N. (1995), in Ranger (ed) Society in Zimbabwe Liberation War. Harare: University of Zimbabwe Publications.

[11]. Bhebhe, N. (1995), Soldiers in Zimbabwe Liberation War. Vol.1. London: James Currey.

[12]. Catholic Commission for Peace and Justice (1989), Breaking the Silence. Building True Peace. A Report on the disturbances in Matabeleland and Midlands.

[13]. Chapman, J (1989), French Power in Africa. Oxford: Basil Blackwell.

[14]. Chimhundu R, (1992), Early Missionaries and the ethno linguistic factor during the invention of Tribalism in Zimbabwe: Journal of African History Vol. 33 (1992). Cambridge: University Press.

[15]. Eriksen, H. T. (2002), 2nd edition, Ethnicity and Nationalism: Anthropological Perspectives. London: Pluto Press.

[16]. Fardon, R. (1996), The person, ethnicity and the problem of identity in West Africa, in I. Fowler and D. Zeitlyn (eds), African Issues.

[17]. Ferguson, J. (1990), The Anti-Politics Machine: "development", depoliticization, and bureaucratic control in Lesotho, Cambridge University Press.

[18]. Henkel, H and Stirrat, R.L. (2001), "Participation in Spiritual Duty; Empowerment as Secular Subjection," in Cooke, B. And Kothari, U (eds). Participation, The New Tyranny? UK: Zed Books.

[19]. Hyden, G. (2006), African Politics in Comparative Perspective. New York: Cambridge University Press.

[20]. Jenkins, R. (1987), Transnational Corporations and Uneven Development: The Internalisation of Capital and the Third World, New York: Methuen

[21]. Kellas, J.G (1998), The Politics of Nationalism and Ethnicity. Palgrave, McMillan, London. 
[22]. Kriger, N. (1988), “The Zimbabwe War of Liberation. Struggles within the Struggle” Journal of Southern African Studies $14.2 \mathrm{pp}$ 304-322.

[23]. Kriger, N. (2006), "From Patriotic Memories to Patriotic History in Zimbabwe, 1990-2005. Third World Quarterly 27 (6).

[24]. Mabhena, C. 2010. "Visible Hectares, Vanishing Livelihoods: A Case for the Fast Track Land Reform Programme in Southern Matabeleland, Zimbabwe." PhD diss., University of Fort Hare.

[25]. Makambe, E. P. (1992), The mobilisation of African labour across the Zambezi for the Zimbabwean colonial period. African Studies, informationworld.com.

[26]. Moore, D. S. (2005), Suffering for territory: race, place and power in Zimbabwe USA: Duke University Press

[27]. Moyo S (1995), The Land Question in Zimbabwe. SAPES Books Harare

[28]. Moyana, H. and Sibanda M. (1999), The African Heritage, Book 3, Harare. Zimbabwe Publishing House.

[29]. Munro, R, (1994): Children and Women in Zimbabwe. Situational Analysis; A UNICEF Update, Harare: Mazongororo Paper Converters.

[30]. Nkomo, J. (1984): The story of my life. Harare: SAPES

[31]. Ntsebeza, L. (2006), Democracy Compromised: Chiefs and the Politics of Land in South Africa. Cape Town, HSRC Press

[32]. Nyathi, P. (2001), Traditional Ceremonies of Amandebele: Gweru: Mambo Press

[33]. Ottaway, M. (1999), State failure, collapse and reconstruction, (ed) Milliken Jennifer. Massachusetts: Blackwell Publishers.

[34]. Ranger, T.O. (1999), Voices from the Rocks, nature, culture and history in the Matopos Hills of Zimbabwe. Oxford: James Currey.

[35]. Ranger, T.O (1993), "The Invention of Tradition Revisited: The case of Colonial Africa". In T. Ranger and O. Vaughan, (eds), Legitimacy and the State in Twentieth Century Africa. London: Palgrave.

[36]. Ranger, T.O (1985), The Invention of Tribalism in Zimbabwe. Mambo Occasional papers.

[37]. Raftopoulos, B. and Phimister, I. (2004), "Mugabe, Mbeki and the politics of Anti-Imperialism", Review of African Political Economy, 101.

[38]. Raftopoulos, B. and Phimister, I. (2004), Zimbabwe Now: The Political Economy of Crisis and Coercion, Historical Materialism, No. 12. 4.

[39]. Richards, J. (ed. 1999), State, Conflict and Democracy in Africa. Colorado: Lynne Reinner Publishers.

[40]. Robins, S. L. (1994), Contesting the Social Geometry of State Power: A case study of Land Use Planning in Matabeleland, Zimbabwe, Social Dynamics, 20:2.

[41]. Roseberry, W. and O'Brien, J. (1991), Introduction to Jay O’Brien and William Roseberry (eds). Golden Ages: Imagining the past in Anthropological History. Berkeley: University of California Press.

[42]. Scoones, I. (1996), Range management science and policy politics, polemics and pastures in southern Africa, in M. Leach and R. Mearns (eds), The lie of the land: Challenging Received Wisdom on the African Environment. London: James Currey and Indiana: Indiana University Press.

[43]. Schech, S and Haggis, J. (2000), Culture and Development. A critical Introduction. Oxford University Press. Oxford

[44]. Sithole M. (2000), The salience of Ethnicity in African Politics. Journal of Asian and African Studies, Vol 20 No 3-4. Blackwell Publishers.

[45]. Stoneman, C. And Cliffe, L. (1989), Zimbabwe: Politics, Economics and Society: London: Printer Publishers.

[46]. Turton, A. R. (1997), Southern African Hydro-politics: Development trajectories of the Zambezi basin states and South Africa. Memrew occasional paper no. 7: Harare. 